Research Article

\title{
Experimental and Theoretical Study of a New Technique for Mixing Self-Compacting Concrete with Marble Sludge Grout
}

\author{
Rayed Alyousef $\mathbb{C D}^{1}{ }^{1}$ Mohamed Amine Khadimallah, ${ }^{1,2}$ Chokri Soussi, ${ }^{3,4}$ \\ Omrane Benjeddou $10,{ }^{3,5}$ and Malek Jedidi ${ }^{3,5}$ \\ ${ }^{1}$ Prince Sattam Bin Abdulaziz University, College of Engineering, Civil Engineering Department, Alkharj, Saudi Arabia \\ ${ }^{2}$ University of Carthage, Polytechnic School of Tunisia, Laboratory of Systems and Applied Mechanics, Tunis, Tunisia \\ ${ }^{3}$ Higher Institute of Technological Studies of Sfax, Department of Civil Engineering, Sfax, Tunisia \\ ${ }^{4}$ University of Sfax, Faculty of Science of Sfax, Georessources, Materials, Environment and Global Change Laboratory, \\ Sfax, Tunisia \\ ${ }^{5}$ University of Tunis El Manar, National Engineering School of Tunis, Civil Engineering Laboratory, Tunis, Tunisia
}

Correspondence should be addressed to Omrane Benjeddou; benjeddou.omrane@gmail.com

Received 8 July 2018; Accepted 2 September 2018; Published 23 September 2018

Academic Editor: Robert Černý

Copyright (c) 2018 Rayed Alyousef et al. This is an open access article distributed under the Creative Commons Attribution License, which permits unrestricted use, distribution, and reproduction in any medium, provided the original work is properly cited.

Currently, marble waste is valued by incorporating powders, obtained by drying and grinding sludge resulting from marble blocks cutting operation, or the aggregates, obtained by crushing the solid waste, on self-compacting concrete. These two procedures require a lot of energy. This experimental and theoretical work focuses on the direct incorporation of marble sludge in self-compacting concrete. The first part needs the study of the rheological behavior of the marble sludge grout (MSG) as a function of the added water amount. For this, different grouts were prepared and tested by varying the water/sludge ratio. In the second part, four self-compacting concretes (SCCs) were mixed with MSG having different water/sludge ratios in order to validate a new technique of gassing self-compacting concrete with MSG. The test results show that the marble grains of grout is totally dispersed when the water/sludge ratio was equal to 1.2. The results also show that the gassing with MSG allows us to obtain SCC having both self-compacting property and self-leveling property compared to SCC made by adding marble filler to the cementitious matrix.

\section{Introduction}

Marble is a metamorphic rock resulting from the transformation of pure limestone [1]. Waste marble powder is an inert material which is obtained as an industrial byproduct during sawing, shaping, and polishing of marble and causes a serious environmental problem [2]. This powder should be inactivated properly without polluting the environment. The most suitable inactivating method nowadays is recycling because it provides some advantages such as protecting the natural resources, energy saving, contributing to economy, decreasing the waste materials, and investing for the future [3].
Recycling of waste powders in concrete is a promising option for clean environment. Several researchers studied the incorporation of marble powder into cement-based products such as normal concrete, high-strength concrete, and self-compacting concrete.

The marble powder materials can be successfully and economically utilized to improve some properties of fresh and hardened self-compacting concrete [4]. The effects of substitution of cement with marble powder on the rheological and mechanical properties of self-compacting mortar (SCM) and self-compacting concrete (SCC) were studied [5-10]. The results indicate an improvement in the workability and the compressive strength of SCC with the use of marble powder. 
The marble powder was also used as an additive material in blended cement [11]. This cement has been obtained by intergrinding marble powder with Portland cement clinker at different blend ratios. Obtained results indicate that adding $10 \%$ of marble powder provides cement that conforms to EN 197-1 standard [11].

In addition, the marble powder was also used in concrete production, as partial replacement of Portland cement $[3,12-16]$. The results show that the optimal replacement level of Portland cement by marble powder was found at $10 \%[12]$.

In general, grout must be characterized by four essential properties: the penetrability, the stability, the mechanical characteristics, and the durability. The two main parameters influencing the grout penetrability are the granularity of its solid phase and its rheological characteristics (fluidity). The penetrability of the grout is also strongly influenced by the rheological properties of the grout. In particular, the fluidity must be such that the grout penetrability can be achieved so as not to degrade the granular structure.

This experimental and theoretical study is a continuation of our work on the valorization of marble waste [17]. This work focuses on the direct incorporation of marble sludge in self-compacting concrete in order to avoid the technical disadvantages for obtaining a marble powder: grinding after drying which require a lot of energy.

The first part of this work needs the study of the rheological behavior of MSG as a function of the added water amount. For this, different grouts were prepared and tested by varying the water/sludge ratio. In the second part, four self-compacting concretes (SCC) were mixed with grouts having different water/sludge ratios in order to validate a new technique of gassing self-compacting concrete with MSG.

\section{Materials and Methods}

\subsection{Materials}

2.1.1. Marble Sludge. The chemical analysis of marble sludge, performed with an atomic absorption spectrometry "AAS" according to the requirements of EN ISO 15586 [18], is presented in Table 1. The results show that the marble sludge is too rich in calcite $\left(\mathrm{CaCO}_{3}=93.30 \%\right)$, and it is devoid of all clay and organic matter [19]. This last result was confirmed by the result of the methylene blue test, performed according to the requirements of NF P 94-068 [20] The result shows that the sludge does not contain any clay fraction because its methylene blue value (MBV) is equal to 0.45 .

Figure 1 shows the particle-size distribution curve of the marble sludge carried out by the sedimentation method, according to the standard NF P 94-057 [21]. According to this curve, the maximum particle size of marble grains is 63 micron.

In addition, the absolute density and the Blaine specific surface (BSS) of the marble sludge are, respectively, $2.69 \mathrm{~g} / \mathrm{cm}^{3}$ and $9459 \mathrm{~cm}^{2} / \mathrm{g}$.
Finally, the Atterberg limits of the marble sludge were also determined. They are calculated according to the requirements of ASTM D4318-17 [22]. The results of this test are shown in Table 2.

According to the results presented in Table 2, the initial water content and liquidity limit of the marble sludge are, respectively, equal to $30 \%$ and $31 \%$. Indeed, the initial water content in the sludge represents its liquidity limit. The undefined plasticity limit indicates that the sludge is free from any fine clay proportion. This result was confirmed by the VBS value which is in the order of 0.45 .

2.1.2. Cement. The cement used was CEM I 42.5, in conformity with the standard NF EN 197-1 [23]. The chemical composition of this cement is shown in Table 3 . The absolute density and the bulk density of the used cement are, respectively, equal to 3.08 and $1.03 \mathrm{~g} / \mathrm{cm}^{3}$. In addition, its BSS value is equal to $3100 \mathrm{~cm}^{2} / \mathrm{g}$.

2.1.3. Aggregates. The physical characteristics of the aggregates used in the preparation of concrete specimens are shown in Table 4.

2.1.4. Admixture. The employed admixture was a superplasticizer (SP) used to increase markedly the workability of concrete. The degree of saturation of SP, determined by the Marsh cone test in accordance with the standard NF P18-507 [24], shows that the maximum of the ratio superplasticizer/cement is equal to $1.2 \%$.

2.2. Methods. This study aims to valorize of the sludge waste of the cutting operation of marble cutting. The main purpose of this work is to investigate the direct incorporation of marble sludge in self-compacting concrete.

The experimental study is composed of two main parts: MSG rheological behavior and a new technique for mixing self-compacting concrete with MSG.

\subsubsection{Experimental Study of MSG Rheological Behavior.} The most important condition that must satisfy the MSG is its penetrability on the granular matrix of concrete. The two main parameters influenced the penetrability are the granularity of its solid phase and its rheological characteristics (fluidity).

To determine the optimal water content of the MSG that gives the best penetration and the sufficient rheology, we investigate an experimental study of MSG rheological behavior as a function of the added water amount. For this, eight MSGs termed MSG1, MSG2, MSG3, MSG4, MSG5, MSG6, MSG7, and MSG8 were prepared with different water/sludge ratios, respectively, equal to $0.6,0.8,1,1.2,1.4$, $1.6,1.8$, and 2 . It should be noted that the marble sludge amount is constant for all grouts. The composition of the MSG is presented in Table 5.

To prepare the different MSGs, we used a propeller mixer with a controlled rotation speed. In order to 
TABle 1: Chemical composition of marble sludge.

\begin{tabular}{lcccccccccccc}
\hline Component & $\mathrm{CaCO}_{3}$ & LOI & $\mathrm{Ca}$ & $\mathrm{CaO}$ & $\mathrm{MgO}$ & $\mathrm{SiO}_{2}$ & $\mathrm{Fe}_{2} \mathrm{O}_{3}$ & $\mathrm{Al}_{2} \mathrm{O}_{3}$ & $\mathrm{MgCO}_{3}$ & Sulfur (S) & $\mathrm{Moisture}$ \\
\hline Percentage & 93.30 & 42.60 & 37.36 & 52.28 & 0.50 & 3.00 & 0.39 & 0.14 & 1.04 & 0.03 & 0.20 \\
\hline
\end{tabular}

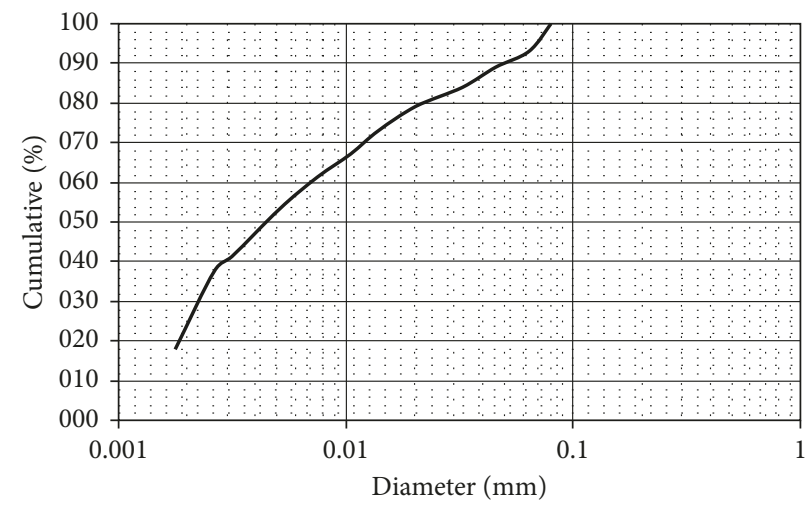

Figure 1: Particle-size distribution curve of the marble sludge.

TABLE 2: Atterberg limits of the marble sludge.

\begin{tabular}{lcccccc}
\hline Parameter & $\begin{array}{c}\text { Water content, } W \\
(\%)\end{array}$ & $\begin{array}{c}\text { Plasticity limit, PL } \\
(\%)\end{array}$ & $\begin{array}{c}\text { Liquidity limit, LL } \\
(\%)\end{array}$ & $\begin{array}{c}\text { Plasticity index, } \\
\text { PI }\end{array}$ & $\begin{array}{c}\text { Liquidity index, } \\
\text { LI }\end{array}$ & Consistency index, \\
Value & 30 & Undefined & 31 & Undefined & Undefined & Undefined \\
\hline
\end{tabular}

TABle 3: Chemical composition of cement.

\begin{tabular}{lcccccccccc}
\hline Component & $\mathrm{CaO}$ & $\mathrm{SiO}_{2}$ & $\mathrm{LOI}$ & $\mathrm{K}_{2} \mathrm{O}$ & $\mathrm{MgO}$ & $\mathrm{Fe}_{2} \mathrm{O}_{3}$ & $\mathrm{Al}_{2} \mathrm{O}_{3}$ & $\mathrm{RI}$ & $\mathrm{SO}_{3}$ \\
\hline Percentage & 63.53 & 20.19 & 3.21 & 0.46 & 1.07 & 3.75 & 4.92 & 0.61 & 1.57 \\
\hline
\end{tabular}

Table 4: Physical characteristics of aggregates.

\begin{tabular}{|c|c|c|c|c|c|c|c|}
\hline Aggregates & $\begin{array}{l}\text { Bulk density } \\
\left(\mathrm{g} / \mathrm{cm}^{3}\right)\end{array}$ & $\begin{array}{l}\text { Absolute density } \\
\left(\mathrm{g} / \mathrm{cm}^{3}\right)\end{array}$ & Absorption (\%) & Finesse module & $\begin{array}{c}\text { Equivalent of } \\
\text { sand (\%) }\end{array}$ & Los Angeles (\%) & MDE (\%) \\
\hline Natural sand $0 / 2$ & 2.42 & 1.47 & & 1.85 & 91 & & \\
\hline Crushed sand $2 / 4$ & 2.43 & 1.32 & 0.32 & 4.8 & 98 & & \\
\hline Gravel 4/8 & 2.55 & 1.42 & 0.32 & & & 17 & 13 \\
\hline Gravel 8/12 & 2.55 & 1.40 & 0.32 & & & 17 & 13 \\
\hline
\end{tabular}

TABLE 5: Composition of MSG.

\begin{tabular}{lccccc}
\hline Grout reference & Marble sludge $(\mathrm{g})$ & Water $\left(\mathrm{cm}^{3}\right)$ & Water content “ $W$ ” $(\%)$ & Water/sludge & Grout volume $\left(\mathrm{cm}^{3}\right)$ \\
\hline MSG1 & 2000 & 1200 & 60 & 0.6 & 1665 \\
MSG2 & 2000 & 1600 & 80 & 0.8 & 1 \\
MSG3 & 2000 & 2000 & 100 & 1.2 & 2065 \\
MSG4 & 2000 & 2400 & 120 & 1.4 & 2465 \\
MSG5 & 2000 & 2800 & 140 & 1.6 & 2865 \\
MSG6 & 2000 & 3200 & 180 & 1.8 & 3265 \\
MSG7 & 2000 & 4600 & 200 & 2 & 4065 \\
MSG8 & 2000 & 4000 & & 4465 \\
\hline
\end{tabular}

completely disperse the marble sludge grains in the water, to eliminate any possible agglomerate, and to obtain homogeneous MSG, the total mixing time was fixed as 7 minutes at a maximum rotation speed of 700 revolution/ min, thus guaranteeing the same mixing energy for all the tested MSGs. 
The detailed mixing procedure is as follows:

Step 1. Introduction of marble sludge into the water, $1 \mathrm{~min}$ at 400 revolutions/min.

Step 2. Grout mixing, $6 \mathrm{~min}$ at 700 revolutions/min.

We also verified that, at the end of each mixing, no segregation is visible at the bottom of the mixing bowl and that the MSG temperature is always within a limited range of $24 \pm 1^{\circ} \mathrm{C}$.

All tests on MSG were made within $90 \mathrm{~s}$ after the end of mixing in order to ensure the same MSG state.

\subsubsection{Experimental Study of a New Technique for Mixing Self-} Compacting Concrete with MSG. This part of our experimental investigation needs us to select the most appropriate mixing method for grout and concrete, and thus to obtain SCC having good rheological properties, choosing the better mixing method of the SCC with the MSG is essential. For this purpose, we prepare and test four samples of the selfcompacting concretes SCC1, SCC2, SCC3, and SCC4 mixed with MSG having different water/sludge ratios.

The excess paste method was used for formulating the four self-compacting concretes according to the requirements of the standard EN 206-1 [25]. This method considers the concrete as a biphasic material, consisting of a fluid phase (paste) and solid phase (aggregates) [26]. The four SCCs are "SCC30" with a flow class of SF2. For this class, the slump value must be between 66 and $75 \mathrm{~cm}$ and the minimum required 28 -day compressive strength is $30 \mathrm{MPa}$. The cement dosage was set as $400 \mathrm{~kg}$, and the weight ratio of gravel to sand was set at $1(G / S=1)$.

Table 6 presents the dosage of the four self-compacting concretes.

The four concretes, SCC1, SCC2, SCC3, and SCC4, differ by the mixing methods. The mixing methods are presented in Table 7 .

The four concretes were tested, in their fresh state, through the following tests: slump flow test, L-box test, $\mathrm{V}$-funnel test, sieve stability test, and measuring the air content were performed on fresh concrete (Figure 2).

\section{Results and Discussions}

\subsection{Rheological Properties of the MSG}

3.1.1. Influence of the Water/Sludge Ratio on the Grain Dispersion of Grout. In order to evaluate the water content influence on the dispersal potential of the grains in the different prepared MSGs and on its incidence to their rheological behavior, we passed all the mixed grouts through the 63 micron sieve (Figure 3).

The dispersion percentage of the different MSGs is presented in Figure 4. We remarked that the increase of the water/sludge ratio makes the passage of grout through sieve very easy. We also remarked that if the water/sludge ratio is equal to 1.2 , the MSG is totally passed through the sieve.
We can thus conclude that the more the water/sludge ratio, the more the MSG disperses totally. This is due to the increase of the intergranular distance between MSG grains and the decrease of the volume concentration of the solid. Consequently, the interaction number and the intensity of the friction between grains were reduced during the MSG flow.

This result can be theoretically approved by the following formula, which estimates the intergranular distances " $e$ ":

$$
e(\mu \mathrm{m})=2.10^{4} \frac{(\text { water/sludge }-0.12)}{\mathrm{BSS}},
$$

where BSS is the Blaine specific surface of the marble sludge $\left(\mathrm{cm}^{2} / \mathrm{g}\right)$.

The intergranular distances, of the different MSGs, estimated using Equation (1), for BSS $=9450 \mathrm{~cm}^{2} / \mathrm{g}$, are given in Table 8. According to the given results, we can confirm that the distance between MSG grains increases with the water/sludge ratio.

It is noted that the total dispersion of the grains does not mean a stable grout. However, using a mini-cone test, we observed the segregation phenomenon for the MSG with the water/sludge ratio higher than 1.4 .

Finally, the particle-size distribution curves of all MSGs are prepared by the sedimentometric test according to the NFP 94-068 standard [21]. The results showed that the particle-size distribution curves of the grains of MSG with 1.2 water/sludge ratio are the same as that the natural sludge. Indeed, the total dispersion of MSG grains with the water/sludge ratio equal to 1.2 was also confirmed.

3.1.2. Influence of the Water/Sludge Ratio on the Grout Density. The density of MSG was determined with the Fann four-scale mud balance. The measurement results of MSG densities are presented in Table 8 and Figure 5.

According to the results presented in Figure 5 and Table 8, we can notice that the experimental density of MSG decreases by increasing the water/sludge ratio. This is due to the increase in the free water amount between the marble grains which is related to both the increase of water content and to the decrease of volume concentration of the solid of MSG.

The last result was confirmed by the theoretical density values of different MSGs given by the following expression:

$$
d_{\text {The }}=\frac{\left(M_{\mathrm{s}}+M_{\mathrm{w}}\right)}{\left(V_{\mathrm{s}}+V_{\mathrm{w}}\right)},
$$

where $M_{\mathrm{s}}$ is the sludge mass, $M_{\mathrm{w}}$ is the water mass, $V_{\mathrm{s}}$ is the sludge volume, and $V_{\mathrm{w}}$ is the water volume.

$V_{\mathrm{s}}$ and $V_{\mathrm{w}}$ can be presented, respectively, by the two following relations:

$$
\begin{gathered}
V_{\mathrm{s}}=\frac{M_{\mathrm{s}}}{\rho_{\mathrm{s}}}, \\
V_{\mathrm{w}}=\frac{M_{\mathrm{w}}}{\rho_{\mathrm{w}}},
\end{gathered}
$$


TABLE 6: Composition of $1 \mathrm{~m}^{3}$ of SCC with marble sludge.

\begin{tabular}{lccccccc}
\hline Cement $(\mathrm{kg})$ & Sludge $(\mathrm{kg})$ & Gravel 8/12 $(\mathrm{kg})$ & Gravel 4/8 $(\mathrm{kg})$ & Sand 0/2 $(\mathrm{kg})$ & Sand 2/4 $(\mathrm{kg})$ & Water $(\mathrm{l})$ & SP $(\mathrm{kg})$ \\
\hline 400 & 100 & 720 & 180 & 720 & 180 & 200 & 4.4 \\
\hline
\end{tabular}

TABLE 7: The different mixing methods.

\begin{tabular}{|c|c|c|c|c|}
\hline \multirow{2}{*}{$\begin{array}{l}\text { Concrete } \\
\text { reference }\end{array}$} & \multirow{2}{*}{$\begin{array}{l}\text { Dry mixing } \\
1 \mathrm{~min}\end{array}$} & \multicolumn{2}{|c|}{ Wet mixing } & \multirow{2}{*}{$\begin{array}{l}\text { End of mixing } \\
\text { Total } 5 \mathrm{~min}\end{array}$} \\
\hline & & $1.5 \mathrm{~min}$ & $2.5 \mathrm{~min}$ & \\
\hline \multirow{3}{*}{$\begin{array}{l}\text { SCC1 } \\
\text { procedure 1 } \\
\text { SCC2 } \\
\text { procedure 2 } \\
\text { SCC3 } \\
\text { procedure } 3\end{array}$} & $\begin{array}{l}\text { Aggregates + cement } \\
+ \text { marble sludge }\end{array}$ & $+2 / 3$ of water & $\begin{array}{c}+1 / 3 \text { of water mixed with } \\
\text { the superplasticizer }\end{array}$ & \multirow{5}{*}{$\begin{array}{l}\text { SCC on the } \\
\text { fresh state }\end{array}$} \\
\hline & Aggregates + cement & $\begin{array}{c}\text { + Grout MSG2 (100 kg of sludge } \\
\text { dispersed in } 80 \mathrm{~L} \text { of water) }\end{array}$ & $\begin{array}{l}+120 \mathrm{~L} \text { of water mixed with } \\
\text { the superplasticizer }\end{array}$ & \\
\hline & Aggregates + cement & $\begin{array}{l}+ \text { Grout MSG4 (100 kg of sludge } \\
\text { dispersed in } 120 \mathrm{~L} \text { of water) }\end{array}$ & $\begin{array}{l}+80 \mathrm{~L} \text { of water mixed with the } \\
\text { superplasticizer }\end{array}$ & \\
\hline \multirow{2}{*}{$\begin{array}{l}\text { SCC } 4 \\
\text { procedure } 4\end{array}$} & \multirow[t]{2}{*}{ Aggregates + Cement } & \multicolumn{2}{|c|}{$\begin{array}{c}+ \text { Grout MSG8 (100 kg of sludge dispersed in } 200 \mathrm{~L} \text { of } \\
\text { water + superplasticizer) }\end{array}$} & \\
\hline & & $2 / 3$ & $1 / 3$ & \\
\hline
\end{tabular}
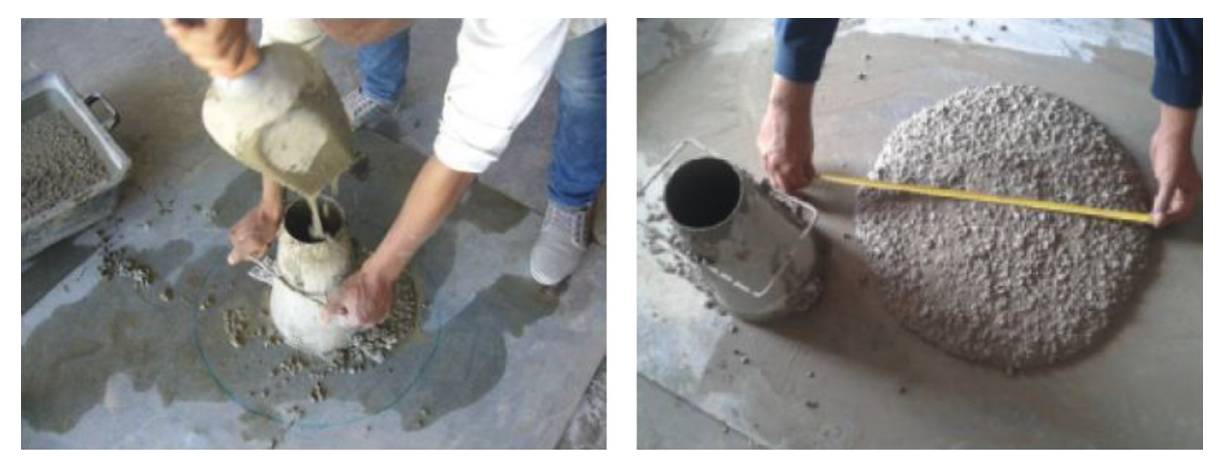

(a)
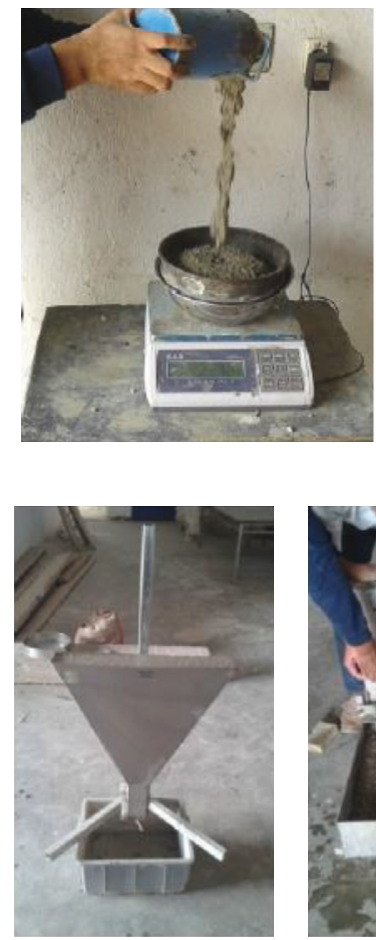

(c)

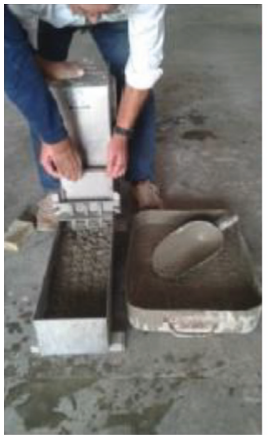

(d)

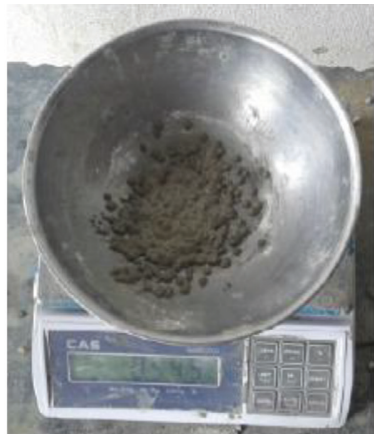

(b)

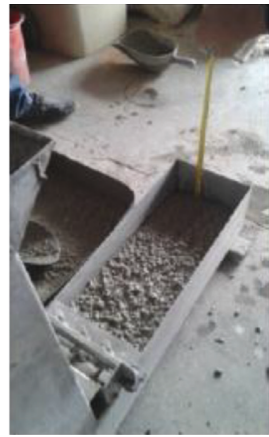

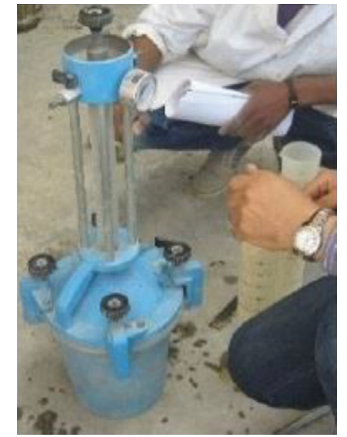

(e)

Figure 2: The tests carried out on SCC. (a) Slump flow test. (b) Sieve stability test. (c) L-box test. (d) V-funnel test. (e) Air content test. 


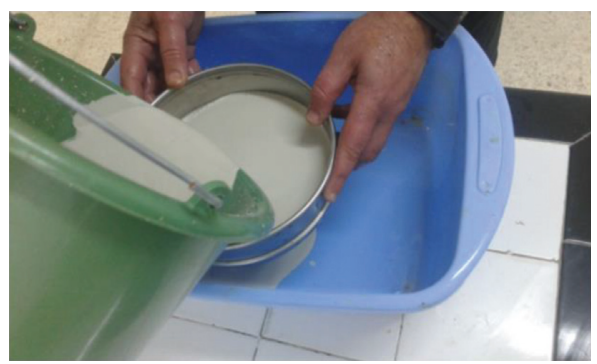

(a)

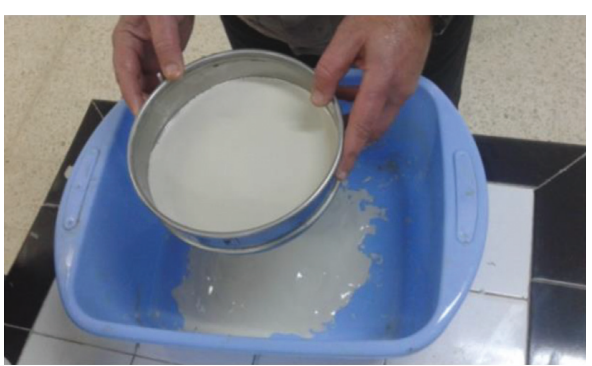

(b)

FIGURE 3: MSG test sieving.

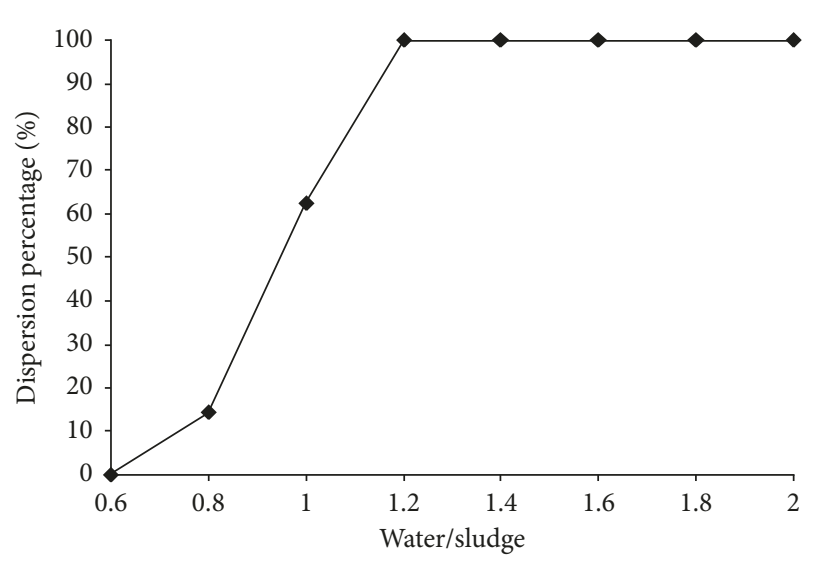

FIGURE 4: Dispersion percentage as a function of the water/sludge ratio of the different MSGs.

TABLE 8: The physical properties of the different MSGs.

\begin{tabular}{lcccccc}
\hline $\begin{array}{l}\text { Grout } \\
\text { reference }\end{array}$ & Water/sludge & $\begin{array}{c}e \\
\text { (micron) }\end{array}$ & Density & \multicolumn{3}{c}{$\begin{array}{c}\text { Volume } \\
\text { concentration } \\
\text { of solid }\end{array}$} \\
\hline MSG1 & 0.6 & 1.010 & 1.62 & 1.646 & 0.376 & 0.382 \\
MSG2 & 0.8 & 1.439 & 1.52 & 1.536 & 0.313 & 0.317 \\
MSG3 & 1 & 1.862 & 1.45 & 1.457 & 0.269 & 0.271 \\
MSG4 & 1.2 & 2.285 & 1.395 & 1.399 & 0.235 & 0.236 \\
MSG5 & 1.4 & 2.708 & 1.35 & 1.354 & 0.209 & 0.209 \\
MSG6 & 1.6 & 3.132 & 1.30 & 1.318 & 0.185 & 0.188 \\
MSG7 & 1.8 & 3.555 & 1.27 & 1.289 & 0.168 & 0.171 \\
MSG8 & 2 & 3.978 & 1.25 & 1.264 & 0.1548 & 0.156 \\
\hline
\end{tabular}

where $\rho_{\mathrm{s}}$ and $\rho_{\mathrm{w}}$ are the unit weights, respectively, of sludge and of water.

By using Equations (2)-(4), the relationship between theoretical density and water/sludge ratio of MSG can be expressed by the following relation:

$$
d_{\text {The }}=\frac{\left(M_{\mathrm{w}} / M_{\mathrm{s}}+1\right)}{\left(M_{\mathrm{w}} / \rho_{\mathrm{w}} M_{\mathrm{s}}+1 / \rho_{\mathrm{s}}\right)} .
$$

The results presented in Figure 5 and Table 8 show that the theoretical and the experimental density values present a good agreement. Indeed, the influence of the water/sludge ratio on the MSG density was confirmed.

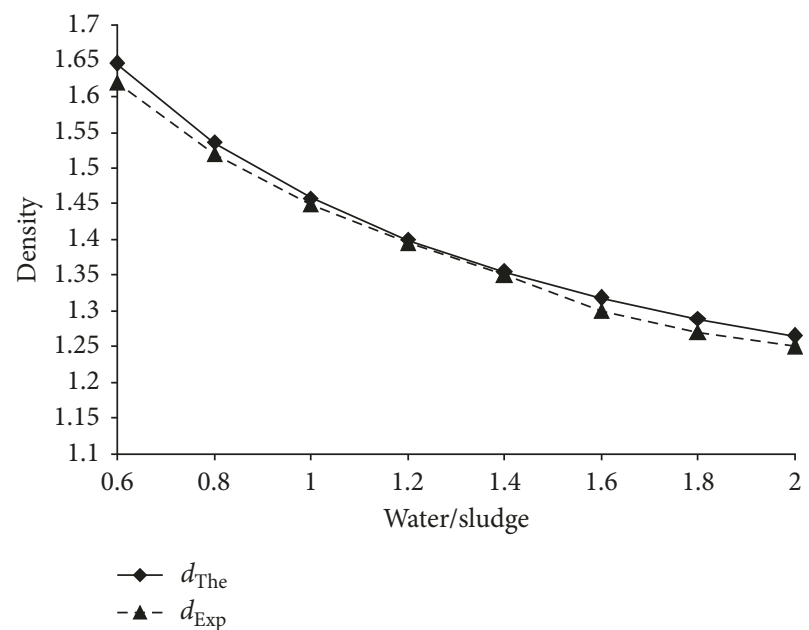

Figure 5: Experimental and theoretical densities and water/sludge ratio relationships.

3.1.3. Influence of the Water/Sludge Ratio on the Volume Concentration of Solid. The volume concentration and granularity of the solid phase of grout are two of the most important factors affecting the rheological characteristics of the grout.

The theoretical expression of the volume concentration of the solid of the grout, denoted $\left(V_{c}\right)_{\text {The }}$, is as follows:

$$
\left(V_{\mathrm{c}}\right)_{\mathrm{The}}=\frac{V_{\mathrm{s}}}{\left(V_{\mathrm{s}}+V_{\mathrm{w}}\right)} \text {. }
$$

By using Equations (3), (4), and (6), the relationship between the theoretical volume concentration of the solid and the water/sludge ratio can be expressed by the following relation:

$$
\left(V_{\mathrm{c}}\right)_{\text {The }}=\frac{1}{\left(\rho_{\mathrm{s}} / \rho_{\mathrm{w}} \cdot M_{\mathrm{w}} / M_{\mathrm{s}}+1\right)} .
$$

The experimental expression of the volume concentration of the solid of the grout, denoted $\left(V_{\mathrm{c}}\right)_{\text {Exp }}$, is as follows:

$$
\left(V_{c}\right)_{\operatorname{Exp}}=\frac{d_{\operatorname{Exp}}}{\rho_{\mathrm{s}}\left(M_{\mathrm{w}} / M_{\mathrm{s}}+1\right)} .
$$

The theoretical and the experimental volume concentrations of the solid of the different tested MSGs are presented in Figure 6 and Table 8. According to the results, we 


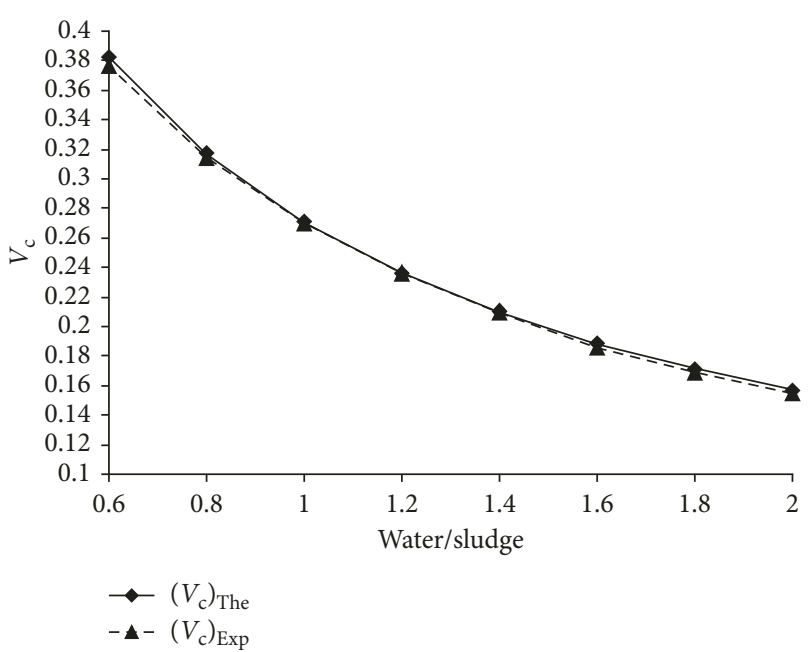

FIGURE 6: Experimental and theoretical volume concentrations of the solid and water/sludge ratio relationship.

can conclude that the volume concentration of the solid decreases by increasing the water/sludge ratio. This is due to the increase of the water amount. We also remarked that the theoretical and the experimental solid concentrations by volume values present a good agreement.

3.1.4. Marsh Funnel Viscometer Test. The Marsh funnel is used to measure the time required to fill a set volume of grout. The flow through the small tip at the end of the funnel is related to the rheological properties of the fluid being measured. Marsh funnel flow time is used as an indicator of the relative consistency of fluids. Longer time to fill one quart indicates that the MSG is more viscous. The calibration for Marsh funnel time is 26 seconds per quart for fresh water. This test was required according to the standard NF P18-507 [24].

Flow time of the different MSGs is presented in Figure 7 and Table 9. According to these results, we remarked that the measured flow time increases rapidly with the water content. We also remarked that if the water/sludge ratio is below 0.6 , the MSGs no longer flow, they are not deformed under the effect of its own weight, and its Marsh funnel viscosity tends to move towards infinity. If the water/sludge ratio is equal to 1.4 (corresponding to a low concentration of the solid), the MSG viscosity decreases until stabilization around $26 \mathrm{sec}-$ onds which is the Marsh viscosity of water, and consequently, the studied MSG has the same rheological behavior as water.

The results presented in Figure 7 and Table 9 also show the influence of the superplasticizer on the MSG behavior. Measurements show that, for a water/sludge ratio equal to 0.6 , the mix has a character of a grout which proves that the superplasticizer can play the role of a fluidifant. It is also noted that, for the water/sludge ratio equal to 1.4, the MSGs have a flow time very close to that of water.

Marsh funnel time provides a single data point that cannot be used alone to specify the grout rheology. Using the

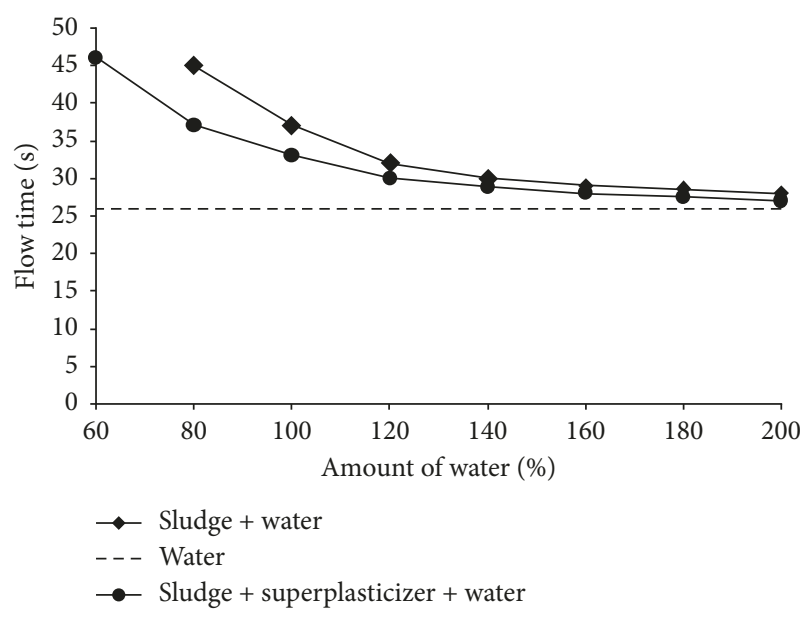

Figure 7: Marsh funnel flow time of different MSGs.

flow time and the density, we can determine the equivalent viscosity of MSG by the following expression:

$$
\mu_{\mathrm{e}}=\rho_{\mathrm{g}}\left(\frac{(t-5.5)}{0.039}\right)^{5 / 6}
$$

where $\mu_{\mathrm{e}}$ is the equivalent viscosity in Pa.s, $t$ is the flow time of outflow of the volume $0.95 \mathrm{~L}$ in seconds, and $\rho_{\mathrm{g}}$ is the grout density in $\mathrm{g} / \mathrm{cm}^{3}$.

The equivalent viscosity values of MSG, presented in Table 8 , show that this equivalent viscosity decreases with the increase in the water/sludge ratio.

\subsection{Effect of the Mixing Method on the Rheology of SCC in the Fresh State}

3.2.1. Slump Flow Test. The slump flow test is the simplest and most widely used test method to quantify the workability of SCC [27]. The slump flow, measured according to the standard NF EN 12350-8 [28], is a value system for the ability of concrete to deform under its own weight against the friction of the surface with no external restraint present. The principle of this test is shown in Figure 2(a).

Table 10 presents the results of the slump flow tests of the four tested SCCs as the function of the mixing method.

According to the results presented in Table 10, we remarked that, for the concrete SCC1, which we incorporate directly the sludge in its natural state (water content equal to $30 \%$ ), the dispersion of the grain sludge is almost absent. We also remarked that after mixing procedure cycle, marble sludge was divided into several slurries. Indeed, for this concrete, there is no increase in the paste volume, no homogeneity, and no deformability. Finally, we can conclude that the concrete SCC1 is not considered as a selfcompacting concrete.

With the same reasoning, the sludge dispersed in advance in $1 / 3$ of the total quantity of the gassing water did not give the character of a grout (concrete SCC2). In view of the lack of water, the marble grain dispersion is partial and the concrete deformability is low. This is justified with the low slump flow value of $40 \mathrm{~cm}$. 
TABLE 9: Marsh funnel flow time and equivalent viscosity of different MSGs.

\begin{tabular}{|c|c|c|c|c|c|c|}
\hline \multirow{2}{*}{ Grout reference } & \multirow{2}{*}{ Water/sludge } & \multirow{2}{*}{ Density, $\rho_{\mathrm{g}}\left(\mathrm{g} / \mathrm{cm}^{3}\right)$} & \multicolumn{2}{|c|}{ Marsh funnel flow time (s) } & \multirow{2}{*}{ Equivalent viscosity, $\mu_{\mathrm{e}}(\mathrm{MPa} \cdot \mathrm{s})$} & \multirow{2}{*}{ Comment } \\
\hline & & & Grout & Grout with superplasticizer & & \\
\hline MSG1 & 0.6 & 1.62 & - & 46 & - & Stuck \\
\hline MSG2 & 0.8 & 1.52 & 45 & 37 & 486 & Normal flow \\
\hline MSG3 & 1 & 1.45 & 37 & 33 & 384 & Normal flow \\
\hline MSG4 & 1.2 & 1.395 & 32 & 30 & 320 & Normal flow \\
\hline MSG5 & 1.4 & 1.35 & 30 & 28.8 & 290 & Normal flow \\
\hline MSG6 & 1.6 & 1.29 & 29 & 28 & 267 & Normal flow \\
\hline MSG7 & 1.8 & 1.22 & 28.5 & 27.5 & 248 & Normal flow \\
\hline MSG8 & 2 & 1.16 & 28 & 27 & 232 & Normal flow \\
\hline
\end{tabular}

We also remarked that mixing the concrete SCC3 according to the procedure 3 leads to the increase of the concrete deformability and then the slump flow increases to $70 \mathrm{~cm}$. We also noticed that the best deformability has been obtained with this mixing procedure. The $70 \mathrm{~cm}$ slump flow value shows that the concrete SCC3 belongs to the class SF2. This result demonstrates the positive effect of the use of MSG dispersed in advance in which its objective is to improve the SCC deformability.

The increase in deformability is due to the fineness of marble sludge $\left(9450 \mathrm{~g} / \mathrm{cm}^{2}\right)$ which is greater than that of cement $\left(3100 \mathrm{~g} / \mathrm{cm}^{2}\right)$. This contributes to the improvement of the workability of the concrete and to the increase of the paste volume since the density of the marble sludge is lower than that of cement. This increase of the paste volume and the dispersion of the marble particles in the water tend to remove the particles sand from each other thereby reducing the friction at the granulate interface. In addition, the increase in the paste volume contributes to the improvement of workability, plasticity, and homogeneity of the selfcompacting concrete.

Figure 8 presents the effects of the water/sludge ratio on the paste volume of the different tested self-compacting concretes.

The results also showed that the good quality of the MSG obtained by dispersion of the marble sludge in $2 / 3$ of the total gassing water amount improves the granulometry of the paste which reduces the intergranular friction between the different fine grains. Indeed, both the free water and the deformability of SCC increase.

Regarding the procedure 4, dispersing the sludge in the total amount of the gassing water gives a very fluid and segregated concrete (SCC4 concrete). This is due to the hyperfluidity of the MSG and to the superplasticizer effects on its viscosity. We also noticed that the superplasticizer did not act completely with the cement and consequently the deformability decreases. This is justified by the low slump flow value of about $50 \mathrm{~cm}$ with the segregation of even grains of the MSG. This affects the stability of SCC and consequently reduces its resistance to segregation. Finally, we can conclude that the concrete SCC4 has no self-compacting character.

Since the two mixing procedures 1 and 2 produce two concretes SCC1 and SCC2 that do not have a selfcompacting character, for the rest of the tests, we are interesting to study only the rheology of SCC3 and SCC4.
3.2.2. Sieve Stability Test. The sieve stability test was carried out according to the standard NF EN 12350-11 [29]. To perform the sieve stability test, a sample of 10 liter of concrete was allowed to rest for $15 \mathrm{~min}$. Then 2 liter of it was poured on a $5 \mathrm{~mm}$ sieve from a height of $500 \mathrm{~mm}$, and the percentage of the sample passing the sieve was reported (Figure 2(b)). It has been reported that the variability of test results is poor, especially when the segregation is severe.

The results of the sieve stability test are presented in the Table 11. These results show that the mixing procedure 4 leads to a decrease of the resistance to segregation (for SCC4, the sieve stability is equal to $18 \%$ ). In the contrary, the mixing procedure 3 gives a very a high resistance to segregation (for SCC3, the sieve stability is equal to $1.4 \%$ ).

3.2.3. V-Funnel Test. The V-funnel flow time (Figure 2(c)) was carried out according to the requirements of NF EN 12350-9 [30]. Nonuniform flow of concrete from the funnel suggests a lack of segregation resistance. The $\mathrm{V}$-funnel results were related to concrete viscosity, passing ability, and segregation resistance [31]. A long flow time can be due to high paste viscosity or high interparticle friction.

According to the results presented in Table 11, the flow times of the two concretes SCC3 and SCC4 are, respectively, 8.45 and $15.25 \mathrm{~s}$. We can conclude that the increase of the MSG fluidity at a water/sludge ratio equal to 1.2 leads to the decrease of the flow time of the selfcompacting concrete. Beyond this threshold and despite that the MSG is hyperfluid, the observed segregation delays the flow time.

Finally, according to the concordance between horizontal and vertical flows, the mixing procedure 3 gives both self-compacting and self-leveling concretes (SCC3).

3.2.4. L-Box Test. The L-box test is used to investigate the flow rate and passing ability of SCC in confined spaces [32]. It measures the reached height of fresh SCC after passing through the specified gaps of steel bars flowing within a defined flow distance (Figure 2(d)). After the concrete comes to rest in the apparatus, the heights of the concrete at the end of the horizontal portion, h2, and in the vertical section, h1, are measured to compute the blocking ratio, h2/h1.

The results presented in Table 11 show that the ratio h $2 /$ h1 decreases with the increase of the marble sludge 
Table 10: Slump flow results.

\begin{tabular}{|c|c|c|}
\hline Concrete reference & Slump flow $(\mathrm{cm})$ & Photo \\
\hline SCC1 & Undefined & \\
\hline
\end{tabular}
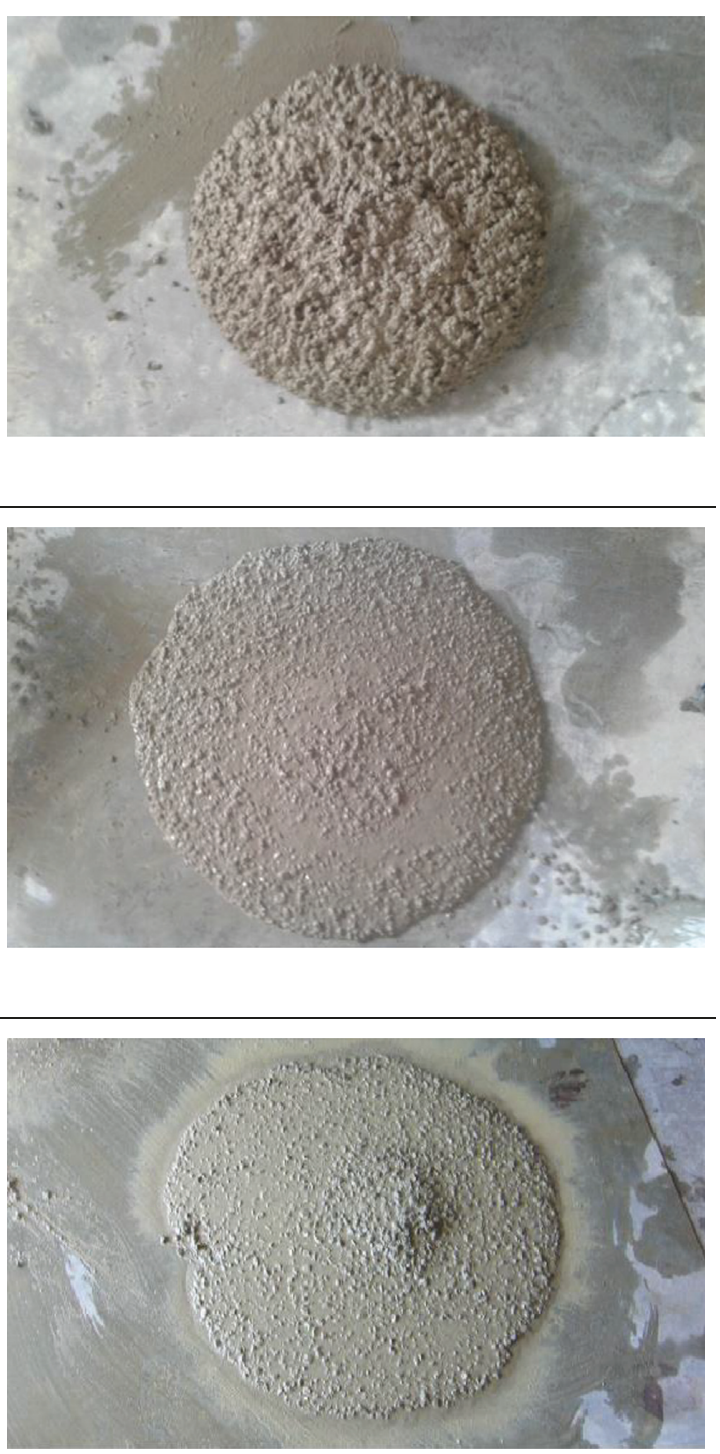

amount. This result is a consequence of the increase in the viscosity of SCC with the large amount of marble sludge.

From the values obtained, we notice that SCC4 is outside the recommended range $(\geq 0.8): H 1 / H 2=0.4$, hence a risk of blockage. On the contrary, the concrete obtained by the mixing procedure $3, \mathrm{SCC} 3$, increases the filling rate. This improves the filling and passage capacitance and consequently prevents concrete blockage in the vicinity of the bars. 


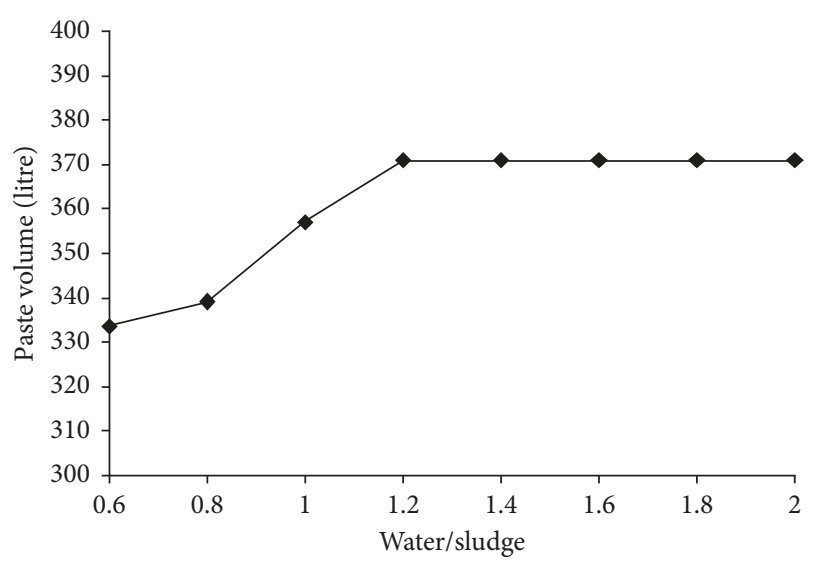

FIGURE 8: The effect of the water/sludge ratio on the paste volume of SCC.

TABle 11: Properties of the two concretes SCC3 and SCC4 in fresh state.

\begin{tabular}{lccc}
\hline Test & $\begin{array}{c}\text { Standard value } \\
\text { for SF2 }\end{array}$ & SCC3 & SCC4 \\
\hline Slump flow (cm) & 66 to $75 \mathrm{~cm}$ & 70 & Undefined \\
L-box & $\mathrm{h} 2 / \mathrm{h} 1 \geq 0.8$ & 0.9 & 0.4 \\
Sieve stability (\%) & $<15 \%$ & 1.4 & 18 \\
V-funnel (flow time (s)) & $8 \leq$ time $\leq 14 \mathrm{~s}$ & 8.45 & 15.25 \\
Air content (\%) & $\leq 5 \%$ & 1.5 & 8 \\
\hline
\end{tabular}

3.2.5. Air Content Test. An air content test is required for checking air-entrained concrete. The method of testing is given in NF EN 12350-7 [33] (Figure 2(e)). The percentage of air content of self-compacting concrete should not exceed $5 \%$.

The results presented in Table 11 show that the two concretes SCC3 and SCC4 have an air content percentage, respectively, equal to 1.5 and $8 \%$. The $1.5 \%$ value proves that the concrete SCC3 has maximum compactness without vibration or clamping, and it is very homogeneous. This homogeneity is due to the good distribution of marble grains and the total dispersion of these grains.

\section{Conclusion}

The objective of this work was to study the possibility to gassing the SCC by a prepared MSG and to evaluate the impact of the mixing method on the properties of SCC in the fresh state.

The main results of this study are as follows:

(1) The marble sludge has sufficient characteristics to be incorporated in SCC

(2) The variation of water content of MSG shows that the water/sludge ratio of 1.2 gives the MSG having an acceptable viscosity that makes the penetrability of MSG easy in the granular matrix

(3) The dispersion of the marble sludge in the water amount less than $2 / 3$ affects the fineness and the real size of the sludge given a partial dispersion of the grains

(4) The dispersion of the marble sludge in the water amount greater than $2 / 3$ has the consequence of removing the grains and having an excess amount of free water causes the segregation phenomenon of SCC

(5) Gassing by MSG seems to be a promising method to directly value marble sludge and to improve the rheological characteristics of SCC

(6) The efficient process is the procedure 3 which respects the universal mixing process: $2 / 3$ of the amount of water for wetting aggregates and $1 / 3$ of water added for the cement hydration reaction

(7) The SCCs obtained by the procedure 3 have both self-leveling and self-leveling characters, a character not obtained when we incorporate the marble filler into the cementitious matrix
Abbreviations
SCC: Self-compacting concrete
MSG: Marble sludge grout
MBV: Methylene blue value
BSS: Blaine specific surface $\left(\mathrm{cm}^{2} / \mathrm{g}\right)$
SP: $\quad$ Superplasticizer $(\mathrm{kg})$
D: $\quad$ Grout density
$d_{\text {Exp }}$ : Experimental density of grout
$d_{\text {The }}$ : Theoretical density of grout
$V_{\mathrm{c}}$ : $\quad$ Volume concentration of solid
$\left(V_{c}\right)_{\text {Exp: }}$ Experimental volume concentration of solid
$\left(V_{c}\right)_{\text {The }}$ : Theoretical volume concentration of solid
$t$ : $\quad$ Flow time (s)
$\mu_{\mathrm{e}}: \quad$ Equivalent viscosity $(\mathrm{MPa})$
$V_{s}: \quad$ Volume of the sludge $\left(\mathrm{cm}^{3}\right)$
$V_{\mathrm{w}}$ : $\quad$ Volume of the water $\left(\mathrm{cm}^{3}\right)$
$\rho_{\mathrm{w}}: \quad$ Water unit weight $\left(\mathrm{g} / \mathrm{cm}^{3}\right)$
$\rho_{\mathrm{s}}: \quad$ Sludge unit weight $\left(\mathrm{g} / \mathrm{cm}^{3}\right)$
$\rho_{\mathrm{g}}: \quad$ Grout unit weight $\left(\mathrm{g} / \mathrm{cm}^{3}\right)$
$M_{\mathrm{s}}$ : $\quad$ Sludge mass (g)
$M_{\mathrm{w}}$ : Water mass (g).

\section{Data Availability}

The data used to support the findings of this study are available from the corresponding author upon request.

\section{Conflicts of Interest}

The authors declare that they have no conflicts of interest.

\section{Acknowledgments}

This project was supported by the Deanship of Scientific Research at Prince Sattam Bin Abdulaziz University under the research project no. 2017/01/7296. 


\section{References}

[1] N. M. Soliman, "Effect of using marble powder in concrete mixes on the behavior and strength of R.C. slabs," International Journal of Current Engineering and Technology, vol. 3, no. 5, 2013.

[2] G. C. Ulubeyli and R. Artir, "properties of hardened concrete produced by waste marble powder," Procedia-Social and Behavioral Sciences, vol. 195, pp. 2181-2190, 2015.

[3] H. Ş. Arel, "Recyclability of waste marble in concrete production," Journal of Cleaner Production, vol. 131, pp. 179-188, 2016.

[4] K. E. Alyamaç and R. Ince, "A preliminary concrete mix design for SCC with marble powders," Construction and Building Materials, vol. 23, no. 3, pp. 1201-1210, 2009.

[5] İ. B. Topçu, T. Bilir, and T. Uygunoğlu, "Effect of waste marble dust content as filler on properties of self-compacting concrete," Construction and Building Materials, vol. 23, no. 5, pp. 1947-1953, 2009.

[6] A. S. E. Belaidi, L. Azzouz, E. Kadric, and S. Kenai, "Effect of natural pozzolana and marble powder on the properties of self-compacting concrete," Construction and Building Materials, vol. 31, pp. 251-257, 2012.

[7] D. Sadek, M. M. El-Attar, and H. A. Ali, "Reusing of marble and granite powders in self-compacting concrete for sustainable development," Journal of Cleaner Production, vol. 121, pp. 19-32, 2016.

[8] M. Gesoğlu, E. Güneyisi, M. E. Kocabağ, V. Bayram, and K. Mermerdaş, "Fresh and hardened characteristics of self compacting concretes made with combined use of marble powder, limestone filler, and fly ash," Construction and Building Materials, vol. 37, pp. 160-170, 2012.

[9] M. Uysal and K. Yilmaz, "Effect of mineral admixtures on properties of self-compacting concrete," Cement and Concrete Composites, vol. 33, no. 7, pp. 771-776, 2011.

[10] T. Uygunoğlu, İ. B. Topçu, and A. G. Çelik, "Use of waste marble and recycled aggregates in self-compacting concrete for environmental sustainability," Journal of Cleaner Production, vol. 84, pp. 691-700, 2014.

[11] H. Y. Aruntaş, M. Gürü, M. Dayı, and İ. Tekin, "Utilization of waste marble dust as an additive in cement production," Materials \& Design, vol. 31, no. 8, pp. 4039-4042, 2010.

[12] A. Rana, P. Kalla, and L. J. Csetenyi, "Sustainable use of marble slurry in concrete," Journal of Cleaner Production, vol. 94, pp. 304-311, 2015.

[13] M. Sardinh, J. De Brito, and R. Rodrigues, "Durability properties of structural concrete containing very fine aggregates of marble sludge," Construction and Building Materials, vol. 119, pp. 45-52, 2016.

[14] A. O. Mashaly, B. A. El-Kaliouby, B. N. Shalaby, A. M. ElGohary, and M. A. Rashwana, "Effects of marble sludge incorporation on the properties of cement composites and concrete paving blocks," Journal of Cleaner Production, vol. 112, pp. 731-741, 2016.

[15] A. A. Aliabdo, M. AbdElmoaty, E. Abd, and E. M. Auda, "Reuse of waste marble dust in the production of cement and concrete," Construction and Building Materials, vol. 50, pp. 28-41, 2014.

[16] A. Ergün, "Effects of the usage of diatomite and waste marble powder as partial replacement of cement on the mechanical properties of concrete," Construction and Building Materials, vol. 25, no. 2, pp. 806-812, 2011.

[17] R. Alyousef, C. Soussi, O. Benjeddou, M. A. Khadimallah, and M. Jedidi, "New technique for mixing self-compacting concrete with marble sludge grout," in Proceedings of 6th International Colloquium E3D 2018 "Water, Waste and Sustainable Development”, Hammamet, Tunisia, March 2018.

[18] NF EN ISO 15586, Water Quality-Determination of Trace Elements Using Atomic Absorption Spectrometry with Graphite Furnace, 2004.

[19] O. Benjeddou, C. Soussi, M. Jedidi, and M. Benali, "Experimental and theoretical study of the effect of the particle size of limestone fillers on the rheology of self-compacting concrete," Journal of Building Engineering, vol. 10, pp. 32-41, 2017.

[20] NF P94-048, Soil: Investigation and Testing-Determination of the Carbonate Content-Calcimeter Method, 1996.

[21] NF P94-057, Soils Investingation and Testing. Granulometric Analysis. Hydrometer Method, 1992.

[22] ASTM D4318-17, Standard Test Methods for Liquid Limit, Plastic Limit, and Plasticity Index of Soils, 2010.

[23] NF EN 197-1: Cement-Part 1: Composition, Specifications and Conformity Criteria for Common Cements, April 2012.

[24] NF P18-507, Additions for Concrete. Water Retention. Method for Measurement of Fluidity by Flowing with the "Cone de Marsh", 1992.

[25] NF EN 206-1, Concrete-Specification, Performance, Production and Conformity, 2014.

[26] P. Nanthagopalan and M. Santhanam, "A simple and systematic mix design procedure for selfcompacting concrete," in Proceedings of 6th International RILEM Symposium on SCC, pp. 54-63, Montreal, Canada, September 2010.

[27] S. Kuroiwa, Y. Matsuoka, M. Hayakawa, and T. Shindoh, "Application of super workable concrete to construction of a 20-story building," in SP-140: High Performance Concrete in Severe Environments, P. Zia, Ed., pp. 147-161, American Concrete Institute, Detroit, MI, USA, 1983.

[28] NF EN 12350-8, Testing Fresh Concrete-Part 8: SelfCompacting Concrete-Slump-Flow Test, 2010.

[29] NF EN 12350-11, Testing Fresh Concrete-Part 11: SelfCompacting Concrete-Sieve Segregation Test, 2010.

[30] NF EN 12350-9, Testing Fresh Concrete-Part 9: SelfCompacting Concrete-V-Funnel Test, 2010.

[31] P. J. M. Bartos, M. Sonebi, and A. K. Tamimi, Workability and Rheology of Fresh Concrete: Compendium of Tests, RILEM, Cachan Cedex, France, 2002.

[32] NF EN 12350-10, Testing Fresh Concrete-Part 10: SelfCompacting Concrete-L Box Test, 2010.

[33] NF EN 12350-7, Testing Fresh Concrete-Part 7: Air Content-Pressure Methods, 2012. 


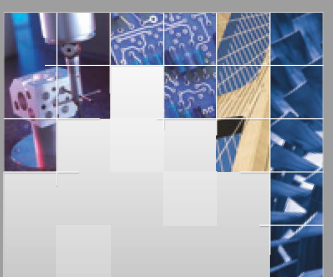

\section{Enfincering}
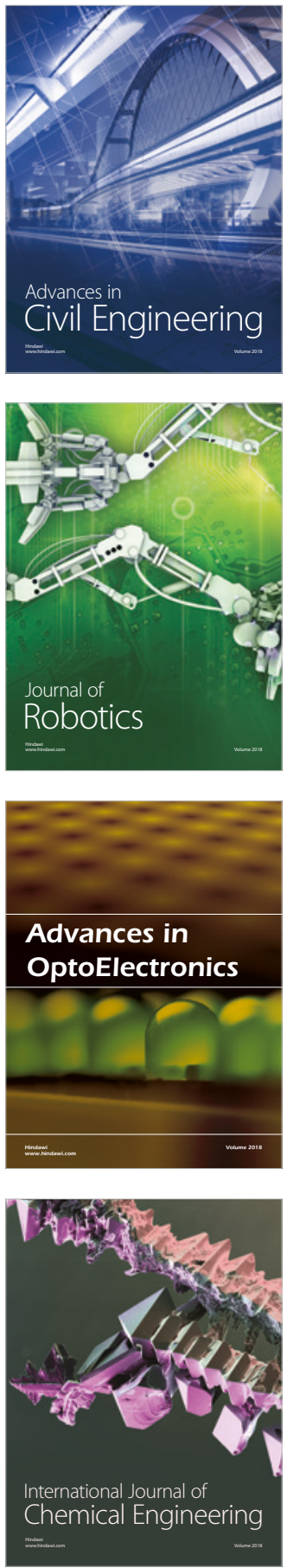

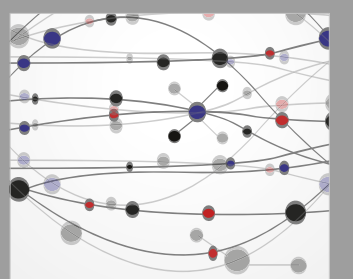

\section{Rotating \\ Machinery}

The Scientific World Journal

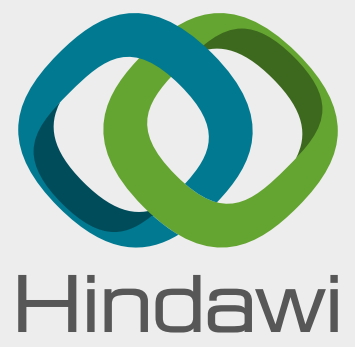

Submit your manuscripts at

www.hindawi.com
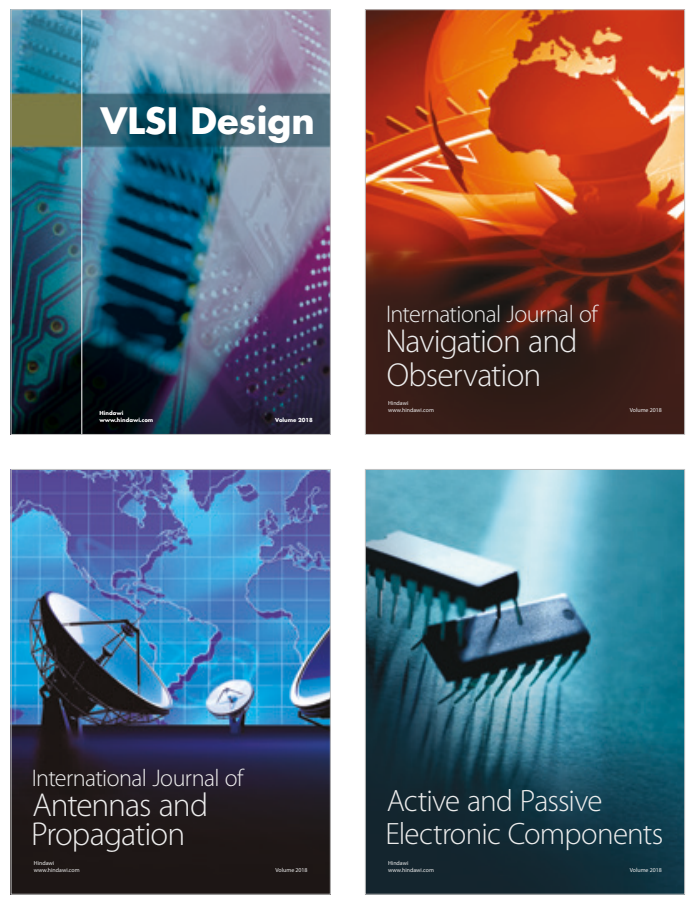
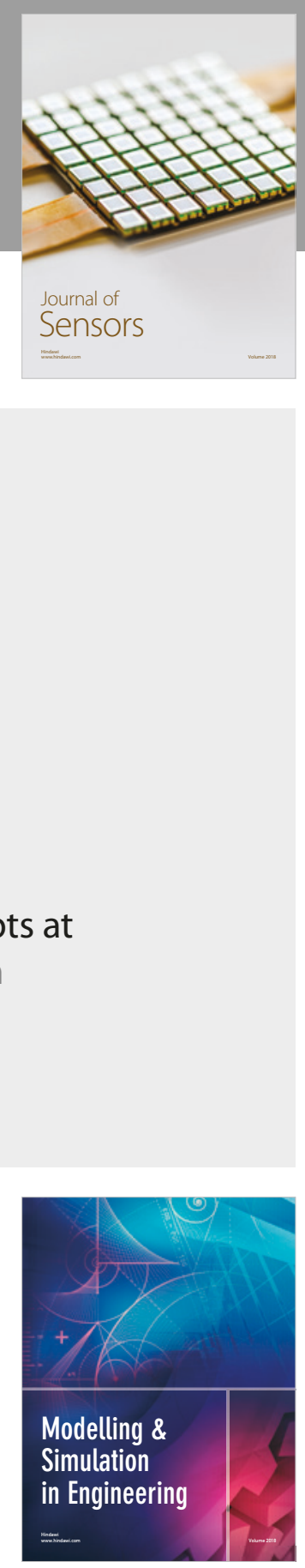

\section{Advances \\ Multimedia}
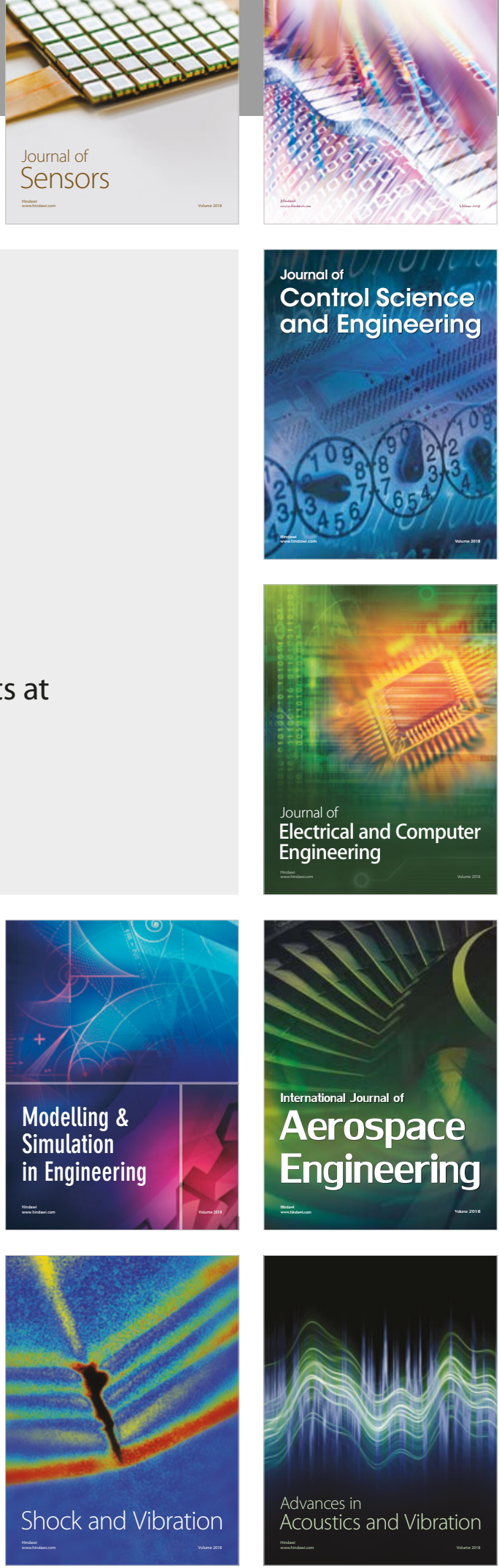